\title{
HISTORICAL AND PEDAGOGICAL ASPECTS AS A SUBJECT OF CONTENT ANALYSIS OF POPULAR SCIENCE PUBLICATIONS
}

\author{
Liudmyla Zelenska ${ }^{1}$, Tetyana Bondar ${ }^{2}$, Oleksiy Bondar ${ }^{3}$ \\ ${ }^{I}$ Doctor of Science, Professor, Kharkiv National Pedagogical University named H. S. Skovoroda, Kharkiv, \\ Ukraine, e-mail: zelenskaya_ludmila@ukr.net, ORCID: https://orcid.org/org/0000-0002-3324-5173 \\ ${ }^{2}$ Postgraduate student of department of pedagogy Kharkiv National Pedagogical University named H. S. \\ Skovoroda, Kharkiv, Ukraine, e-mail: tetanabondar@gmail.com, ORCID: https://orcid.org/0000-0002- \\ 9487-5363 \\ ${ }^{3}$ Research engineer, Radio Astronomical Institute of the National Academy of Sciences of Ukraine, Kharkiv, \\ Ukraine, e-mail: bondarrian@gmail.com, ORCID: https://orcid.org/0000-0002-2474-5256
}

\begin{abstract}
The purpose of the article is to identify the frequency and nature of the coverage of pedagogical problems in the publications of the journal "Science and Society» with demonstration of powerful epistemological potential of automated content analysis. The research methodology is based on a set of general scientific methods - system-structural, diachronic, statistical, problemchronological. The study followed the principles of historicism, objectivity and multifactorialism. Revealed the basic stages of this method and its purpose. Investigated the pedagogical problems and its various aspects (popularization of scientific knowledge; organization of educational process in high school; self-education of adults; pedagogical education of parents; propaganda of state ideology and communist education; training and upbringing of children of preschool and school age), which was found on the pages of the magazine for years: 1973, 1983, 1987, 1990, 1991. An array of text information from the magazine "Science and Society» is being processed using automated text coding techniques through key tokens. The results of the study are presented as diagrams. The Janis coefficient and validity are calculated using formulas. In the analysis takes into account the historical context as meta-knowledge, which allows to expand the perception of research results. The most popular topics in the journal "Science and Society» were discovered and uncovered in 1973, 1983, 1987, 1990, 1991. The results of the study demonstrate an analytical approach to pedagogical issues and can be used to share pedagogical experience and in the organization of non-formal education, in particular of adults.
\end{abstract}

Keywords: content analysis, automated content analysis, pedagogical issues, popular science publication, "Science and Society», «Knowledge» society, Ukraine.

JEL Classification: I0; I20

Formulas: 0; fig.: 2; tabl.: 0; bibl.: 12

Introduction. In recent years, the amount of information that the user operates, growing at a rather rapid pace. Accordingly, it reduces the time for its analysis and processing. One of the ways to solve this problem may be to use the computer technology as an enhancer of intellectual abilities of a human. Modern computing capabilities and software developed in recent years, can significantly accelerate the analysis, processing and digitization of a large amount of information. At the same time, the process of mastering complex software is simplified. Not only computer specialists can use the most complex programs, but also other specialists such as sociologists, pedagogists, psychologists, psychiatrists, economists, etc. As a result, interdisciplinary connections are deepening.

In domestic scientific research increasingly encountered various methods of analyzing information, in particular, content analysis (text-mining, automated, quantitative or qualitative content analysis). 
The concept of content analysis is understood by the method of analyzing information in order to obtain reliable and valid conclusions from texts in the social context of their use by means of intersubjectively agreed rules for the systematization of information [6].

Note that content analysis is an effective tool for studying the content of historical documents, periodicals and reflects the mood of the era. Taking into account the above mentioned, we considering the method of automated content analysis as perspective one to study the problems of the popular science publication «Science and Society», published since 1923. With the support of the People's Commissariat of Education of the USSR. Since 1951 till today it is publishing with the assistance of the society «Knowledge»-public scientific-educational society of Ukraine [14]. The main areas of work of this society are: educational work, organization of education of adults and parents, raising the culture of citizens, informing society about state ideology, popularization of scientific knowledge, publishing activity.

The choice of the magazine «Science and Society» is due to the fact that it is one of the most demanded scientific and popular publications both in the Soviet era and in the times of independent Ukraine. In addition, it serves as a content carrier of relevant information on current pedagogical issues.

The study of pedagogical issues revealed on pages of this popular science publication allows us to thoroughly examine the evolution of this phenomenon in Ukraine in order to identify educational tendencies in the development of public opinion and pedagogy as a science, in particular. Also, this publication is a reflection of the content and activities of the head of the magazine - Society «Knowledge» of Ukraine.

The purpose of the article is to identify the frequency and nature of the coverage of pedagogical issues in the publications of the journal «Science and Society» with demonstration of powerful epistemological potential of automated content analysis.

Literature Review. An important contribution to the development of content analysis has been made by such foreign scholars as Elo S., Kyngas H. (2008) «The qualitative content analysis process» [4], Gavora P (2015) «The State-of-the-Art of Content Analysis» [5]. Deep investigations of this method of information processing were made by Indian scientist Devi B Prasad (2008) «Content analysis: A method of Social Science Research. Research Methods for Social Work» [3], American scientist Krippendorf, K. (2004) «Content Analysis. An introduction to Its methodology» [7] and British scientist Popping R. (2000) «Computer-assisted text analysis» [9].

Scientists White, M., March, E. (2006) in the article "Content Analysis: A Flexible Methodology» [15] describe content analysis as a systematic, rigorous approach to the analysis of documents obtained or created during the study. Important scientific explorations of discussion and classical content analysis were made by domestic scientists Denusova, S. (2014) [2] and Ivanov, O. (2013) [6].

Aims. The aim of the article is to study the periodical «Science and Society» and identify pedagogical aspects and political propaganda by the method of automated content analysis. 
Methods. To solve this goal, the materials of the journal «Science and Society» were analyzed for years: 1973, 1983, 1987, 1990, 1991. The analysis was conducted with the help of automated content analysis, which corresponds to three basic principles of scientific method:

1. Objectivity: clear rules that allow different researchers to get the same results within the same material being studied.

2. Impartiality: the material for analysis was not specifically selected in order to confirm the viewer's point of view.

3. Generalization: the research method can be used by other researchers to another material [3].

The results were processed using the web-based reading and analysis tool.

Results. Automated content analysis was conducted in five stages, in accordance with its methodology [7].

The first stage of the study includes the definition of the subject and object of the study, the selection of content units (words and phrases) to formulate the predictable categories that interest us in terms of the goal.

The object of research is a sample of magazines «Science and Society». The subject is the content of these journals related to the pedagogical and socioeducational context.

At the second stage, the sample size of the magazines «Science and Society» is determined. The selection of the magazines «Science and Society» was elected in $1973,1983,1987$, and 1990 in 1991 in order to identify the difference in the coverage of pedagogical issues, taking into account the specifics of socio-historical processes in Ukraine and trends in the development of the enlightenment movement. The calculated validity of the sample is in the range of $0.8-1$, which allows making grounded conclusions based on the input material.

The third step involves coding by category and quantitative research. Categories are selected using words and phrases related to the topic under study.

These categories are content-independent, which corresponds to the methodology of this analysis [7]. At this stage, the researcher uses an intelligent filter to identify phrases that contain words-markers that match the specified categories [6].

In the fourth stage, trial coding was performed - checking whether the selected content categories are in line with the text, taking place amendments to the coding of the categories. Categories do not repeat and are not interconnected by content.

At the fifth stage, the frequency of appearance of each category (frequency analysis) is counting. The unit of calculation is the number of characters without spaces for elucidacion of each of the category.

In a result of research work using the web-based environment for reading and analysis of the text as categories of content analysis, the following were highlighted: popularization of scientific knowledge, organization of educational process in high school, adult self-education, pedagogical education of parents, propaganda of state ideology and communist education, training and the upbringing of children of 
preschool and school age. For each category separately for each year of the sample a quantitative content analysis was made.

Figure 1 presents the quantitative frequency of each identified category in the periodical «Science and Society» for years: 1973, 1983, 1987, 1990, 1991.

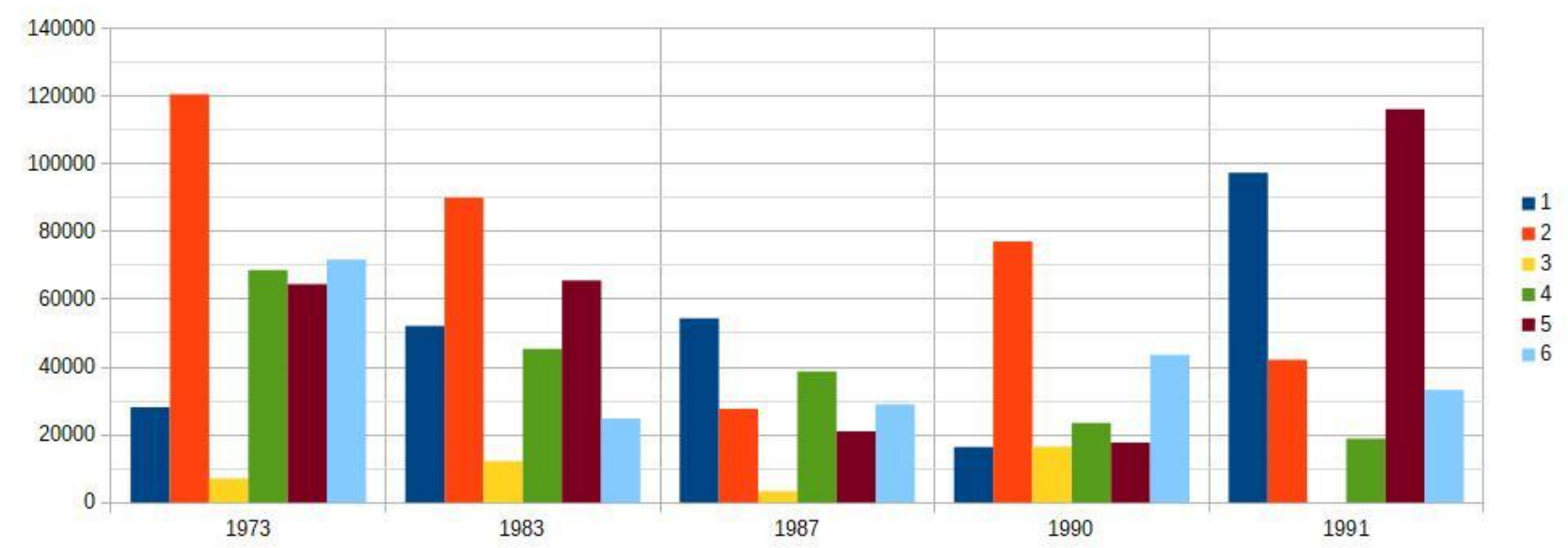

Figure 1. Analysis of the distribution of content by the most common pedagogical issues of the publication «Science and Society» in the years of the sample

where, 1 -Popularization of scientific knowledge; 2-Organization of educational process in high school; 3 -Self-education of adults; 4 -Pedagogical education of parents; 5 - Propagation of state ideology, communist education; 6-Teaching and upbringing of children of preschool and school age.

As seen in Figure 1 in year 1973, the greatest attention was paid to the following pedagogical problems: popularization of scientific knowledge, organization of educational process in higher education, teaching and upbringing of children of preschool and school age in the context of communist ideology, and the smallest self-education of adults. In parallel with this, active ideological propaganda was carried out. This year falls on the time of the so-called Brezhnev stagnation, which is characterized by social, personnel, and economic stability in the state [2].

Among the materials aimed at popularizing scientific knowledge, one should note the active cooperation of the members of the «Knowledge» society of Ukraine with the magazine in discussing the issues of the «technical revolution» and its social consequences; international contacts of specialists of Soviet Ukraine with foreign colleagues on joint research, exchange of scientific and technical documentation, printed materials, participation in international conferences, congresses, meetings, seminars, symposiums, international exhibitions; internship of specialists abroad and learning of forward experience; cooperation with foreign companies and organizations.

The issues of organizing the educational process in the high school concerned the problems of reviewing the content of education, improving the curricula of individual subjects at technical and agricultural activity kinds, and launching the work of new chairs: higher mathematics, cybernetics, mechanized information processing, statistics. The discussion was about on the method of network management and the theory of mass service. Became topical questions of acquisition 
of a special internship of foreign students in higher educational institutions of the Ukrainian SSR, exchange of personnel and equipment between Ukrainian and foreign universities.

The upbringing of a fully developed personality as a cultural, enlightened, spiritually rich person was seen in the formation of its ideological beliefs. Priority was given to the task of upbringing the worker of a socialist society. At the same time, the general secondary education was propaganded to the adult population, since it was believed that a worker with secondary education is working one third more productively than his colleagues with seven-year education. The vocational guidance activity for children and young people with an emphasis on working professions was actively implemented. Particular attention was paid to the pedagogical education of parents on the problems of education and training of children.

Emphasized importance of inheritancethe knowledge and skills in the labor and educational sphere from the older generation to the younger. At the same time, it was stressed on the harmful example of adults, which is expressed in alcoholism, smoking and violations of labor discipline. Also, attention was focused on peculiarities of adolescence and methods of educational influence on the part of parents.

As is known, in these chronological boundaries, the leading role in the upbringing of school-age children belonged to the pioneering organization, the significance of which was emphasized in the pages of the magazine.

There was a need to involve physiologists and hygienists in considering issues on the length and structure of the school day.

The Jānis coefficient for this year was 0.41 (Figure 2). This testifies to a rather positive aggregate assessment of pedagogical issues.

In 1983, the number of symbols to highlight pedagogical issues with an emphasis on the relevance of certain themes has decreased, while maintaining the scope of propaganda of state ideology in publications. This happened against the backdrop of a gradual mutation of the party's course from the construction of communism to underlining the achievements of the then «developed socialism».

Becoming popular the attraction of scientists to popularize scientific knowledge through the publication of «novelties of science and technology», placement on the pages of the journal of public lectures.

An important theme is the effectiveness of training the personnel of the economic profile, since the economic specialties have become more widespread not only in profile higher education, but also in technical, construction, agricultural, etc.

The issue of the absence of courses in social psychology, industrial sociology, technical aesthetics in most universities is discussed. At the same time, attention is focused on improving the material base of institutions of higher education, raising the level of methodological, research and ideological and educational work.

Among the problems of general secondary education,comes to the fore the poorly organized vocational guidance work among high school students, propaganda among the entrants of economic specialties. 
The emphasis is on the education of a person capable of self-replenishment of knowledge and skills building since childhood. The school acts as a leader in the formation of the creative thinking of the younger generation in addressing this issue.

At the same time, raised questions of moral education of children, the role and importance in this process of parents is marked. Propaganding conditions for successful family education, such as: attention to the problems of the child, advice, support, the need for praise from parents for the work.

However, the greater part of the articles contains criticism of nationalist currents, focusing on the benefits of Soviet society and the upbringing of the $«$ Soviet man many international organizations, with a view to strengthening peace among peoples, facilitating the conclusion of conventions on the prohibition of development, production and the proliferation of bacteriological weapons.

The aggregate assessment of pedagogical trends for this year was 0.34 (Figure 2), indicating a slight shift in the assessment of the relevant phenomena. But in general, there is a positive trend.

Reducing attention to the coverage of pedagogical issues can be traced back in 1987. This correlates with the change in the public consciousness, caused by the beginning of the «restructuring aㅔ the policy of publicity. It was at the time of the restructuring that the transition from the positive assessment of the socialist path of development to the negative. As the state gradually ceased to fully oversee the mass media, it became possible to highlight not only the achievements of socialism, but also its congenital and acquired flaws. This moment clearly reflects the Jānis coefficient -0.07 (Figure 2).

On the pages of the magazine apear a new view on the forms of popularization of scientific knowledge, namely, lectures. It is proposed to introduce evenings of questions and answers, «round tables different branches of knowledge, lectures and disputes, etc. Particular attention is paid to moral and ethical issues.

The development of cybernetics and the massive appearance of computers led to discussions on the pages of the magazine on the feasibility of introducing courses in computer science at universities and secondary schools. The authors of the publications emphasized the urgency of reviewing curricula and programs for the preparation of economists, lawyers, engineers, designers and healthcare workers.

The content of school textbooks, educational textbooks for universities is criticized as too «noisy» by non-informative messages.

Most articles relate to the description of cooperation between research institutes and institutions of higher education, emphasizing the tasks of research work in universities and the ways of their solution.

Among the leading areas of self-education, the acquisition of knowledge on ecology is becoming a priority. The urgency of this topic is due to the consequences of the Chernobyl accident (1986). 
At the same time, the pedagogical issues of the magazine are expanding due to coverage of ones related to moral and ethical education, promotion of a healthy lifestyle and deprivation of bad habits, especially alcoholism.

Gradually, the norm of ethics of the magazine becomes a tolerant attitude towards the Orthodox Church as an educational institution and moral authority in society. Traced a change in the valuation of religious life from nihilistic to tolerable. This fact was detected in all the specified categories in 1987.

In 1990, the pedagogical problems became more in demand, the number of such materials in the periodical publication $\Perp$ Science and Society 1987. At the same time, apear a new field in the discussion of pedagogical aspects national. On the pages of the magazine there are calls from commentators to go to teaching subjects in educational institutions in Ukrainian. This is due to the gradual movement toward the independence of Ukraine, which was marked by the adoption by the Verkhovna Rada of the Ukrainian SSR of the Declaration on State Sovereignty [1].

Is being Disseminated information on paid training courses at the Academy of Sciences of the UkrSSR for postgraduate students, graduates of vocational technical schools and working youth, which is preparing for admission to higher education. The idea is that the basis of classes should be independent training of students on the methodological manual.

The pages of the magazine are actively discussing changes in the organization of the educational process in the general education school: the establishment of deep interIsubject conections, the choice of pupils lessons based on their interests, strengthening the humanitarian orientation of education, harmonization of curricula in mathematics and computer science, expanding the content of academic disciplines through additional topics in the field of ecology, economics, modern technologies, types of human activity.

In the context of long-term information isolation for Ukrainian specialists, academics, and teachers, the issue of further training in the educational and research centers of the West is of the utmost importance. This is considered the precondition for the revival of Ukraine's statehood.

The aggregate estimate of pedagogical linking materials for this year was -0.04 (Figure 2), which indicates a somewhat negative emotional coloration of the content of publications.

Trends in the coverage of pedagogical issues in 1990 were continued in 1991, demonstrating somewhat increasing dynamics. The number of materials devoted to pedagogical aspects has increased, especially in publications of the category «popularization of scientific knowledge the focus is on the need for a radical revision of approaches to research by geneticists and breeders because of their isolation from practice. A high school offers a new approach to studying the history of Ukraine. Emphasizes the need for training courses on the history of Ukraine and political science for the general public. Published appeals to scientists on the preparation of publications on a this topic. 
At the same time, on the pages of the magazine for the first time there is information about the organization of seminars, courses on management training and obtaining an international certificate of the manager.

An important issue for parent's education is the AIDS problem and the prevention of this disease. The role of a woman in the potential transmission of this disease to the child is noted. The issues of drug abuse and responsibility for the organization of personal life are revealed.

Pedagogical education of parents focuses on the popularization of knowledge on Ukrainian studies and ethnopedagogy: traditions of respect to parents and the Ukrainian family; family values; ceremonies and beliefs of Ukrainians; national holidays, etc.

Propaganda is intensifying in terms of building up Ukrainian statehood, in particular the national education system. This is due to an increase in the activity of unions and societies, which are aimed at the cultural revival of Ukraine.

The coefficient of Janis was 0 (Figure 2). This indicates an increase in the positive mood in publications and relative optimism.

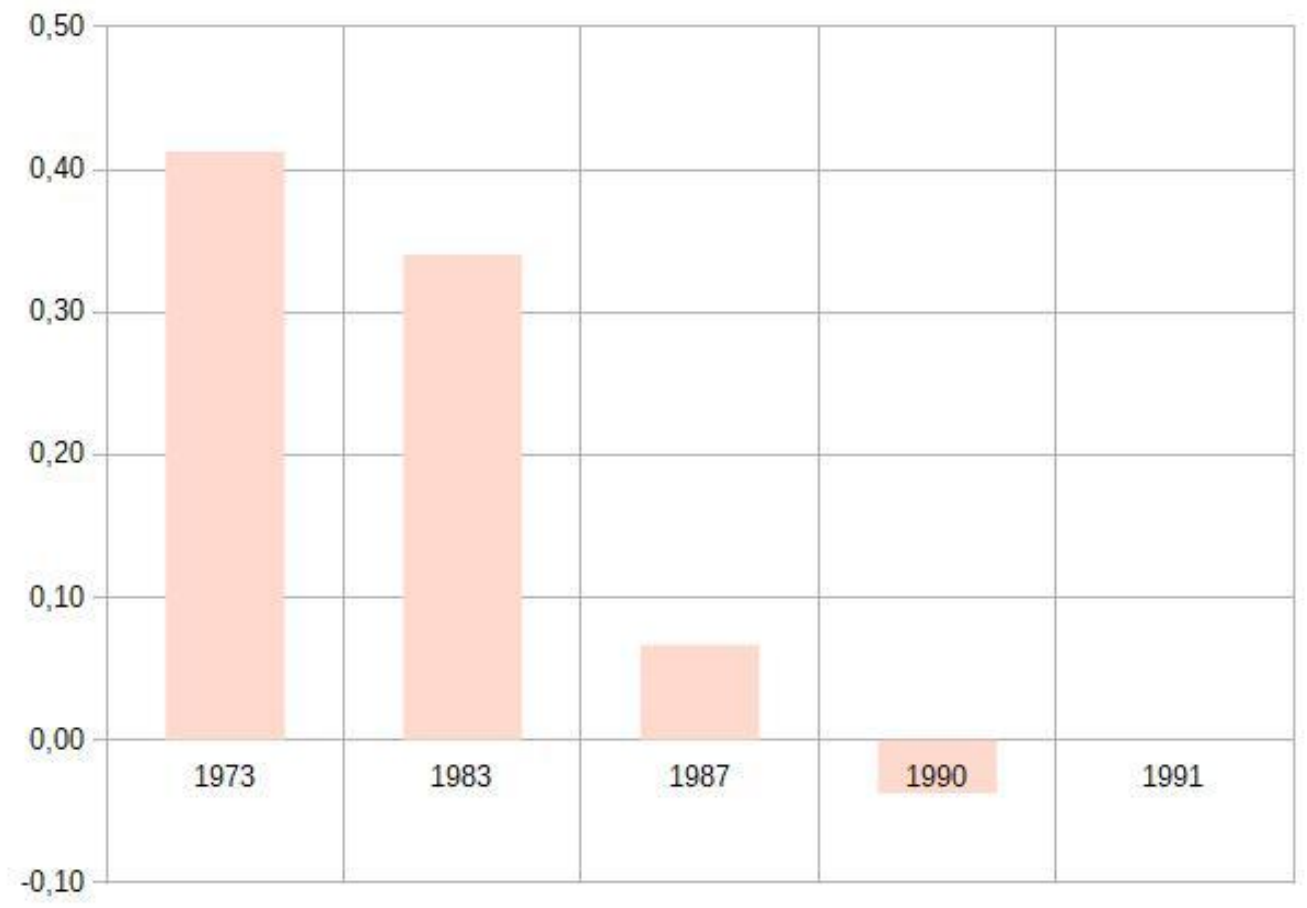

Figure 2. The Janis Coefficient for the «Science and Society» magazine over the years

Discussion. This study, as well as the researches of other scholars [10], proves the effectiveness of using automated content analysis in studying the issues of periodicals.

Taking into account the results of the conducted research, we note that the method of automated content analysis enabled to determine the content of the publications of the journal «Science and Society», to identify the problems and frequency of coverage of pedagogical aspects and orientation of state ideology in years: 1973, 1983, $1987,1990,1991$. The results obtained do not contradict but 
complement the research of foreign scientists [10], which used content analysis to analyze the focus and activity of publications in the study of periodicals.

In 1973, the most attention was paid to the organization of educational process in high school, education and upbringing of children of preschool and school age, the least - self-education of adults. In year 1983, preference was given to publications on psychology, sociology, aesthetics, preparation of economists for the national economy, as well as moral and ethical issues.

In year 1987, the emphasis shifted toward pedagogical education of parents in the following forms: questions and answers, „round tables”, lectures-disputes; attracts attention to ethical issues, environmental education and counteraction to harmful habits. Discussed such issues as introduction of „Rhetoric" and "Informatics" courses in the high school. Appear publications on a tolerant attitude towards the Orthodox Church. Since year 1990, pedagogical issues are considered in the context of the national context of education and upbringing of the younger generation.

The reader's attention is drawn to teaching in educational institutions in Ukrainian language, proposed to revise curricula in secondary schools, substantiated the importance of interdisciplinary connections. Arise publications of vocationaloriented character, proposals for the improvement of professional skills of different branches of knowledge, scientists, and teachers. In year 1991, a growing share of publications devoted to management issues.

Proposed a new approach to studying the history of Ukraine in schools and universities. Spreading a knowledge on Ukrainian culture. The problems of AIDS and its prevention become important.

We share the opinion of scientists $[6 ; 2]$, which prove the expediency of using automated content analysis in the humanities, in particular, in the process of research historical and pedagogical problems.

The advantages of automated content analysis in the process of studying the publications of the journal «Science and Society쁘 were: the identification of valuable historical, socio-cultural, pedagogical experience through the analysis of relevant texts; tracking complex models of human thinking by means of language. At the same time, this method has its own limitations: analysis may require considerable time expenditures and a well-balanced approach to the choice of analytical tools; it is hard to automatize and formulate of conclusions.

The analysis is a synthesis of the capabilities of a computer machine and intellectual abilities of a person. If automation allows you to reduce the time spent on processing the material, then the intellectual potential of a person is able to distinguish content links and deliberately to divide the information by categories. The volume of input data should show the character of the material under investigation.

This study was conducted taking into account possible constraints, which gives the right to make objective conclusions.

Conclusions. In the course of the study, the content of pedagogical issues and the propagation of state ideology in the scientific and educational publication «Science and Society» was revealed with the help of automated content analysis. 
The epistemological potential of automated content analysis enabled us to process 3800 pages of the periodical «Science and Society» in years 1973, 1983, 1987, 1990, 1991.

According to the results of the study, it was established that the pedagogical orientation of publications in 1973, 1983, 1987 was carried out in line with the Soviet realities and had a corresponding ideological coloration. The usual was an optimistic view of the phenomena and processes in contemporary times. Since 1990 the direction of pedagogical problems has become a national context. This fact is most fully observed in 1991. This suggests that the journal «Science and Society early 1990's radically changed approaches to the selection of pedagogical material under the influence of state-building processes in independent Ukraine.

Author contributions. The authors contributed equally.

Disclosure statement. The authors do not have any conflict of interest.

References:

1. Bushina, M., Gurzhiya, O. (2016), Istoriia Ukrainy [History of Ukraine], Cherkasy: CHDTU, 644 p. [in Ukrainian].

2. Denusova, S. (2014), Dyskusiinyi analiz yak sposib rekonstruktsii sotsialno-kulturnykh fenomeniv $u$ khudozhnomu teksti [A discursive analysis as a way of reconstracting socio-cultural phenomena in the artistic text], Visnyk Kyivskoho natsionalnoho linhvistychnoho universytetu - Bulletin of the Kiev National Linguistic University, 17 (2), 57-64. [in Ukrainian].

3. Devi B Prasad (2008), Content analysis: A method of Social Science Research. Research Methods for Social Work, India: Rawat Publicashins [in English].

4. Elo, S., Kyngäs, H. (2008), The qualitative content analysis process. Journal of Advanced Nursing , 62(1), pp. 107-115 [in English].

5. Gavora, P. (2015), The State-of-the-Art of Content Analysis. Journal of Education Scients, 1, pp. 6-18. (retrieved from http://nevelestudomany.elte.hu/index.php/2015/04/the-state-of-the-art-of-contentanalysis/?lang=en) [in English].

6. Ivanov, O. (2013), Klasychnyi kontent-analiz ta analiz tekstu: terminolohichni ta metodolohichni vidminnosti [Classical content analisis and analisis of the taxt: terminological and methodological distinctions]. Visnyk Kharkivskoho natsionalnoho universytetu imeni V. N. Karazina - Bulletin of the VN Karazin Kharkiv National University, 1045 (30), 69-74. [in Ukrainian].

7. Krippendorf, K. (2004). Content Analysis. An introduction to Its methodology. Thousand Oaks, Califirnia, USA: Sage Pulications [in English].

8. Marsh, E. E. (2002), Rhetorical relationships between images and text in Web pages. Unpublished doctoral dissertation, University of Maryland at College Park, Maryland [in English].

9. Popping, R. (2000). Computer-assisted text analysis. London, UK: SAGE [in English].

10. Satu, E. \& Kyngäs, H (2008), The qualitative content analysis process. Journal of Advanced Nursing, 62

(1). (retrieved from https://doi.org/10.1111/j.1365-2648.2007.04569.x) [in English].

11. Shapiro, G., Markoff, J. (2009), A matter of definition. In C. W. Roberts (Ed.), Text analysis for the social sciences, New York, NY: Routledge [in English].

12. Schrodt, P. A., (1996), KEDS (Kansas Event Data System) [computer software], Lawrence: Department of Political Science, University of Kansas.

13.Schrodt, P. A. (2000), TABARI 0.5.1 (Textual Analysis By Augmented Replacement Instructions) [computer software]. Lawrence: Department of Political Science, University of Kansas [in English].

14. Smolij, V. G. (Ets.). (2005), Entsyklopediia istorii Ukrainy [Encyclopedia of the History of Ukraine]. (3nd., Vols. 672), Kyiv: Naukova dumka. [in Ukrainian]

15. White, M., March, E. (2006), Content Analysis: A Flexible Methodology. Library Trends: Research Methods, 55 (1). (retrieved from https://www.ideals.illinois.edu/handle/2142/3654) [in English]. 